\title{
Sanitary risk analysis for farm workers exposed to environmental pollutants
}

\author{
Simone Pascuzzi, Giovanni Russo, Giacomo Scarascia-Mugnozza, Giuseppe Verdiani \\ Department of Agro-Environmental Science (DISAAT), Aldo Moro University of Bari, Italy
}

\begin{abstract}
In Italy, a large number of agricultural areas are contaminated by organic and inorganic polluting substances. In such areas, the agricultural operators come into contact with the environmental contaminants through inhalation and dermic contact with dusts and vapour, and this exposure can potentially alter the biological equilibrium with consequent poisonings and/or work-related illness. The aim of this paper is to apply a methodological procedure for the numerical evaluation of the health risk for agricultural employees operating in open fields or inside greenhouses located in areas contaminated with organic pollutants. This procedure is in response to the lack of calculation models concerning these types of environment and agricultural activities. As a case study, this methodology has been applied to an agricultural area of southern Italy characterised by the presence of pollutants. The results underline that in this area there is a smaller concentration of pollutants in open field cultivations than inside greenhouses owing to a phenomenon of dispersion into the atmosphere. This numeric analysis will later be verified by measurements carried out in situ in order to evaluate the real situation on the ground.
\end{abstract}

\section{Introduction}

Accidents in agriculture usually happen during the cultivation phases and represent $7 \%$ of total work-related accidents (Cividino et al., 2009). In reality, activities that involve considerable risks due to the use of equipment (moving staircases, machinery, sharp tools) and pesticides characterise the primary sector (Tortora et al., 2005).

Correspondence: Simone Pascuzzi, Department of Agro-Environmental Science (DISAAT), Aldo Moro University of Bari, via Amendola 165/A, 70126 Bari, Italy. Tel.Fax: +39.080 .544 .2214 .

E-mail: simone.pascuzzi@uniba.it

Key words: contaminated soil, sanitary risk, farm operator safety.

Contributions: all authors contributed equally to this paper.

Received for publication: 26 July 2012.

Accepted for publication: 9 January 2013.

(C) Copyright S. Pascuzzi, et al., 2012

Licensee PAGEPress, Italy

Journal of Agricultural Engineering 2012; XLIII:e21

doi:10.4081/jae.2012.e21

This article is distributed under the terms of the Creative Commons Attribution Noncommercial License (by-nc 3.0) which permits any noncommercial use, distribution, and reproduction in any medium, provided the original author(s) and source are credited.
In particular, agricultural operators are exposed to the high risk of work-related illness caused by inhalation of and/or dermic contact with harmful substances contained in the plant protection products (Cerruto et al., 2008). In Italy, during 2005, 1280 events of acute poisonings were reported considered to be caused by pesticides (Settimi et al., 2007). Often, cases of acute poisonings were not declared to the qualified authorities either they involved illegal workers or for other reasons (Russo and Anifantis, 2003).

The professional exposure of the agricultural workers to chemical agents can be increased by the simultaneous exposure to other pollutants that are sometimes present in the environmental compartments. Therefore, to the health risk produced by the possible presence of chemical contaminants in soil and water, we must add the safety risk linked to the occupational exposure.

Hence agricultural operators working in polluted areas can come into contact with the environmental contaminants through dust and vapour inhalation and dermic contact, and these exposures can potentially affect the workers' biological equilibrium with consequent poisonings and/or occupational diseases (Cecchini et al., 2010; Barra et al., 2008).

The health risk connected to the exposure to the environmental contaminants must be estimated and appropriately taken into consideration in the evaluation of the chemical risk. The diversity of the chemical agents and the range of the harmful actions produced by each one of the agents makes this a complex operation (Italian Regulation, 2008; Romano et al., 2011; Gino, 2010).

The site-specific environmental health risk analysis is an up-to-date methodology for the numerical evaluation of the occupational risks, founded on technical and legislative standards (Cottica et al., 2010; Cicero et al., 2010). The assessment of the environmental health risk is carried out through the intrinsic characteristics of the pollutants and their concentrations in proximity to the human receptors, the exposure characteristics (inhalation, dermic contact and swallowing), and the exposure time (Nano, 2010). This methodology is founded on the Risk-Based Corrective Action (RBCA), an approach elaborated by the American Society for Testing and Materials (ASTM, 2000) and also included in the Italian technical standard (UNICHIM, 2002).

Nevertheless, this procedure does not consider the detailed characteristics of the agricultural work places or of the operators working in open field or indoor environments such as greenhouses, zootechnic breeding, and so on. Owing to the achievements all over the world in covered horticultural, floral and nursery crops (Scarascia Mugnozza, 1999) and to the consequent increase in greenhouse surface area (approx. 25,000 ha in Italy) (Scarascia Mugnozza et al., 2011), the evaluation of the health risk to agricultural workers is of primary importance in order to adopt suitable prevention and protection measures.

The aim of this paper is to apply a methodological procedure for the numerical evaluation of the health risk for agricultural employees operating in open fields or inside greenhouses located in areas contaminated by organic pollutants. This procedure is in response to the lack of calculation models concerning this type of environment and the characteristics of agricultural activities that concern vegetable production in open fields or inside confined environments (greenhouses, tunnels, etc.). The above-mentioned analytical methodology has been 
applied in the Campania region, a rural area of southern Italy characterised by the presence of agrarian crops both in open fields and inside greenhouse. This area is also compromised by the presence of pollutants released over the years by unauthorised dumps.

\section{Materials and methods}

\section{Theoretical considerations}

The assessment of site-specific environmental health risks caused by the inhalation of environmental pollutants present in the agricultural workplaces has been carried out by the following relationships linked with toxic contaminants (Eq. 1) and carcinogenic contaminants (Eq. 2) (ISPRA, 2008):

$$
H Q=\frac{E}{R f D}
$$

$$
R=E \times S F
$$

where:

$H Q$ [dimensionless] is the hazard index;

$E[\mathrm{mg} /(\mathrm{kg} \cdot \mathrm{d})]$ is the chronic effective daily exposure to contaminant; $R f D[\mathrm{mg} /(\mathrm{kg} \cdot \mathrm{d})]$ the daily reference dose, which is a toxicological property of the pollutants and represents the estimation of the average daily exposure to adverse effects to the human organism outside the workplace over a worker's lifetime;

$R$ [dimensionless] is the increase in cancer risk during life caused by the exposure to the polluter;

$S F[(\mathrm{~kg} \cdot \mathrm{d}) / \mathrm{mg}]$ is the carcinogenic potential for daily polluter dose unit (ISPRA, 2008).

The reference dose (RfD) and the carcinogenic potential $(S F)$ are toxicological characteristics of each pollutant and their values are stored in a specific database (ISS-ISPESL, 2009a, 2009b).

The calculated hazard index $H Q$ and cancer risk increase $R$ values must be compared with the threshold acceptability values in order to verify the health standards of agricultural work places located in contaminated areas. The Italian law in force establishes that acceptable hazard index values as $H Q \leq 1$ and an acceptable increase in cancer risk, related to carcinogenic substances, must be $R \leq 1 \times 10^{-6}$ (Italian Regulation, 2006).

The air scattered pollutants chronic daily intake $(E)$ by the agricultural workers both in open fields and indoor workplaces can be evaluated by the following equation (US EPA, 1997):

$$
E=\frac{\left(C_{p o e} \times B_{0} \times E F \times E F_{d} \times E D\right)}{(B W \times A T)}
$$

where:

$C_{\text {poe }}\left[\mathrm{mg} / \mathrm{m}^{3}\right]$ is the concentration at the exposure point;

$B_{o}\left[\mathrm{~m}^{3} / \mathrm{h}\right]$ is the hourly inhalation;

$E F[\mathrm{~d} / \mathrm{a}]$ is the exposure frequency;

$E F_{d}[\mathrm{~h} / \mathrm{d}]$ is the daily exposure frequency;

$E D[$ a] the years of exposure;

$B W[\mathrm{~kg}]$ is the weight of human receptors;

$A T$ [d] is the average exposure time.

The concentration of pollutants $\left(C_{p o e}\right)$ to which workers are exposed during agricultural activities in the open field is calculated using the equation (ISPRA, 2008):

$$
C_{\text {poe }}=C_{\text {soil }} \times V F_{s s-o u t d o o r}
$$

where:

$C_{\text {soil }}[\mathrm{mg} / \mathrm{kg}]$ is the concentration of pollutants in the superficial soil and $V F_{s s-o u t d o o r}$ the superficial soil-air outdoor volatilisation factor $\left[\mathrm{kg} / \mathrm{m}^{3}\right]$.

In this study, the evaluation of the superficial soil-air outdoor volatilisation factors $V F_{s s-o u t d o o r}$ has been carried out through an analytical model characterised by the following parameters (ISPRA, 2008): the extension of the contamination source in the main wind direction; the wind speed; the mixing zone height in the air; the soil density; the water and the air volume present in the soil; the hydraulic conductivity of the saturated soil; the average time period of the vapour flow of the pollutant; the Henry's constant of the pollutant (ISPRA, 2008). The aforementioned model produces uncertainties in estimating the volatilisation factor owing to the simplified assumptions, but it allows us to avoid direct measurements of the pollutant flow emitted from the soil (Mausacchio and Sanvito, 2012).

The pollutant concentration $\left(C_{p o e}\right)$ to which workers are exposed during agricultural activities inside greenhouses is calculated by the following formula (ISPRA, 2008):

$$
R S S=\sum_{i=1}^{N}\left(M R_{\text {exp }, i}-M R_{\text {prodi, }}\right)
$$

where:

$C_{\text {soil }}$ the concentration of pollutants in the superficial soil and $V F_{\text {ss-indoor }}$ the superficial soil-air indoor volatilisation factor.

In this paper, the evaluation of the superficial soil-air indoor volatilisation factors $V F_{\text {ss-outdoor }}$ has been carried out by another analytical model based on the following parameters (Johnson and Ettinger, 1991): the total surface area involved in pollutant infiltration; the thickness of the foundation; the ratio between indoor volume and pollutant infiltration area; the areal fraction of crack area in the flooring; the water and air volume present in the soil fractures; the average time period of the vapour flow of the pollutant; the indoor air replacements per hour; the Henry's constant of the pollutant.

\section{Study area for application of the proposed methodology}

The aforementioned methodology has been applied to an agricultural area primarily employed to cultivate vegetable crops in open fields and in greenhouses located in a Site of National Interest Flegreo Domitio Coast and Agro Aversano. The presence in the surrounding territory of plants (also unauthorised plants) for waste treatment over a period of years has produced verifiable environmental pollution. In reality, a part of the rural area in question is affected by localised contamination symptoms produced by indenopyrene $\left(C_{\text {soil }}=0.171 \mathrm{mg} / \mathrm{kg}\right)$ and benzo (ghi)perylene $\left(C_{\text {soil }}=0.148 \mathrm{mg} / \mathrm{kg}\right.$ ) (ARPA Campania, 2009). These concentrations have been evaluated through physical and chemical analysis carried out on superficial soil samples collected by the Campania Regional Agency for Environmental Protection (ARPA Campania, 2009).

The following values have been estimated for the agricultural workers considering their demanding physical activity: $B_{0}=2.5 \mathrm{~m}^{3} / \mathrm{h}, E F=150$ $\mathrm{d} / \mathrm{a}, E F_{d}=6 \mathrm{~h} / \mathrm{d}, E D=25 \mathrm{a}, B W=70 \mathrm{~kg}, A T=3750 \mathrm{~d}$.

The considered exposure frequency $(E F)$ value $(150 \mathrm{~d} / \mathrm{a})$ agrees with the greatest number of work-days needed to take advantage of agricultural unemployment benefits (Italian Regulation, 2007), though the 
agricultural workers who work on family farms or without a work contract may be subject to a greater exposure frequency.

The reference values proposed by technical guidelines have been used for each one of the parameters in order to evaluate the $V F_{\text {ss-outdoor }}$ (ISPRA, 2008).

Referring to the calculation of $V F_{\text {ss-indoor, }}$, the reference values suggested by technical guidelines for the average time period of the vapour flow of the pollutant, and for the water and air volume held in the soil fractures, have been used in the numerical model (ISPRA, 2008). The choice of using the reference values for these parameters has been due to the lack of measured data in the study area. On the contrary, there are no reference values for the parameters related to the characteristics of indoor agricultural environments (all buildings, but more specifically greenhouses). They have, therefore, been evaluated on the basis of some theoretical considerations.

The areal fraction of the cracks in the flooring is established as the ratio between the area of the fractures in the surface of infiltration and the total area of the flat surface.

In greenhouses without flooring, the areal fraction of the cracks is equal to 1, as determined for civil and industrial buildings without flooring (ISPRA, 2008). In greenhouses equipped with plastic flooring in which the pollutant's infiltration travels from the soil to the air, the areal fraction of the cracks can be estimated to be equal to 0.01 , as established for paved buildings (ISPRA, 2008).

The environmental health risk assessment for agricultural workers operating in greenhouses has been carried out considering the indoor air exchange during winter months to have more conservative values and then to promote safety. In reality, the high airflow rates implemented are not appropriate for the conditions in summer. The ventilation produced by the openings and the defective tightness of the covering gives rise to 30-60 air replacements per hour during the agricultural activities. The lowest value of 30 air replacements per hour has been considered in the present study in order to increase the environmental health risk, as in these conditions the stay time and the concentration of the pollutants in the greenhouse rise.

The indoor volume of the greenhouse is related to its construction typology while the ratio between the inside volume and the infiltration surface is variable. In fact, considering, for example, greenhouses and tunnels have a $70 \times 10 \mathrm{~m}$ floor area, with a ridge height of $5 \mathrm{~m}$, volume is approximately $3150 \mathrm{~m}^{3}$ for either tunnel greenhouses (Figure 1) or duo-pitched roof greenhouses (Figure 2); a volume of approximately $1680 \mathrm{~m}^{3}$ for tunnels with a ridge height of $3 \mathrm{~m}$ (Figure 3 ). Therefore, in the above example, the relationship between indoor volume and infiltration surface is equal to $4.5 \mathrm{~m}$ for tunnels and duo-pitched roof greenhouses and $2.4 \mathrm{~m}$ for tunnels.

The exposure to contaminants $(E)$ of agricultural workers in outdoor (open field) and indoor (greenhouse) environments and, subsequently, the health risk indexes ( $H Q$ and $R$ ) have been evaluated by applying an ad hoc software which performs the environmental health risk analysis by using criteria and equations defined by Italian technical guidelines (www.reconnet.net).

\section{Results and discussion}

The results of the site-specific environmental health risk analysis carried out for the agricultural workers who operate in the study area either in greenhouses or in tunnels without plastic flooring or in open fields are summarised in Table 1.

The hazard index and the increase in cancer risk for the agricultural workers who operate inside greenhouses and tunnels without flooring or in open fields are far below the legal limits. Therefore, in the study

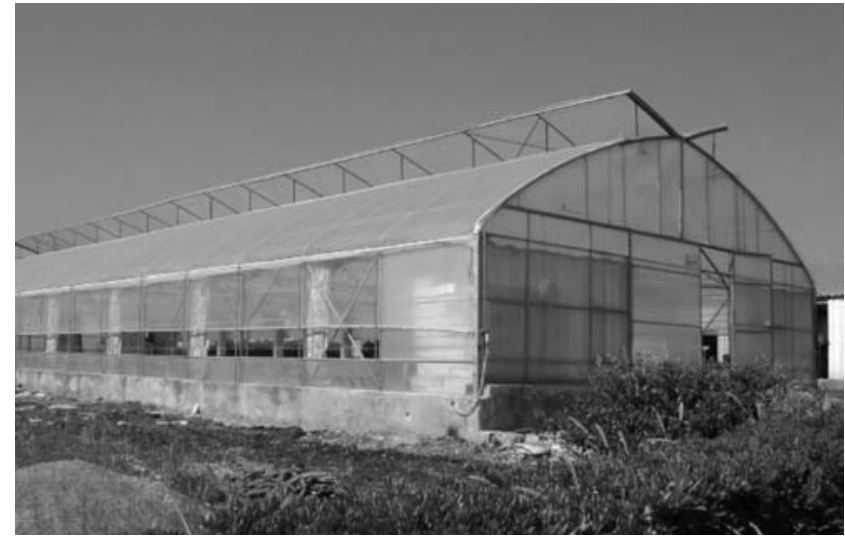

Figure 1. Tunnel greenhouse.

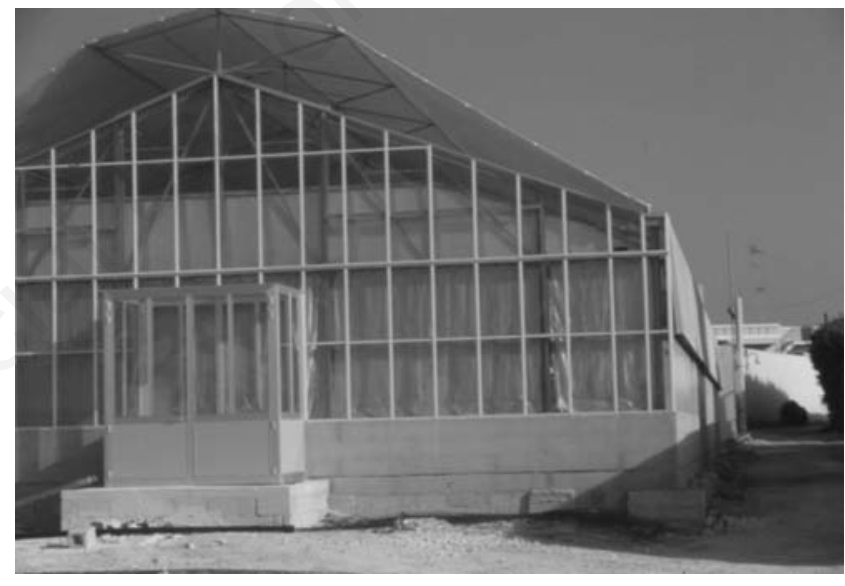

Figure 2. Duo-pitched roof greenhouse.

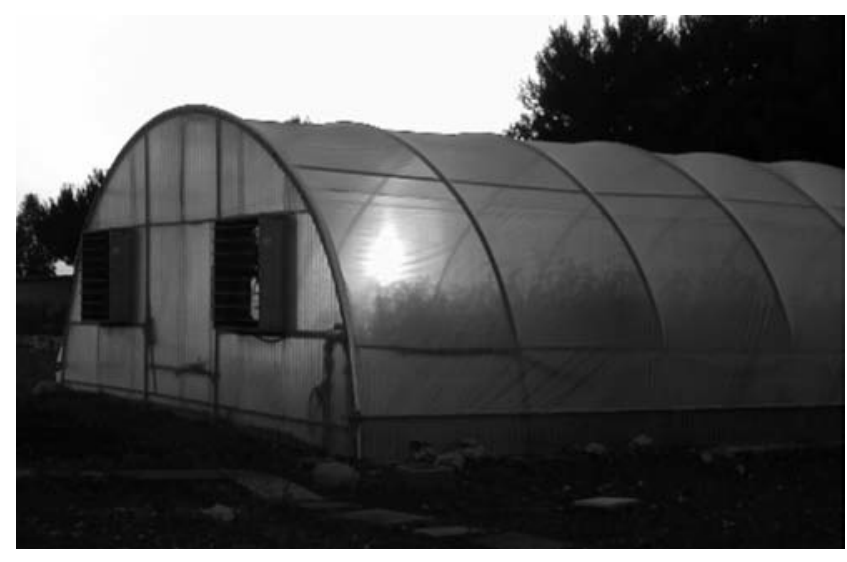

Figure 3. Tunnel. 
area, the indenopyrene and benzo(g,h,i)perylene concentrations in the superficial soil do not produce toxic or carcinogenic effects, and the increase in cancer risk is only caused by the presence of the indenopyrene because benzo(g,h,i)perylene has no carcinogenic effects.

Inside greenhouses or tunnels in which air replacement is produced by side and ridge openings and defective tightness of the covering, the agricultural workers are exposed to a much higher environmental health risk ( $H Q$ and $R$ ) than those working in open fields. Furthermore, the workers inside tunnels are subjected to a greater environmental health risk due to the low volumes and low ratio between indoor volume and infiltration surface.

The global hazard index and global increase in cancer risk values referring to agricultural workers operating inside greenhouses and tunnels with and without plastic flooring are reported in Table 2. Greenhouses and tunnels equipped with flooring ensure a much healthier working environment through the high isolation provided by flooring made with plastic materials. Also, inside greenhouses, workers are exposed to an increase in cancer risk that is always below the legal limits and for which it is not necessary to introduce protective measures. Finally, the ventilation and the presence of flooring ensure pollutant concentrations do not produce a high environmental health risk.

\section{Conclusions}

The methodology of the proposed site-specific environmental health risk analysis for agricultural workers operating in polluted areas allows us to evaluate the air scattered contaminant concentrations both outdoors (open field) and indoors (greenhouse), as well as their hazard index and the increase in cancer risk. This methodology has been applied to estimate an agricultural area in the Campania region of southern Italy, characterised by the presence of pollutants. The results underline that in this area there is a smaller concentration of pollutants on open fields than inside greenhouses owing to the atmospheric scattering phenomenon. Nevertheless, inside greenhouses, the presence of pollutants can be greatly reduced by appropriate building construction and site management. In fact, the indoor greenhouses with a large volume (tunnel greenhouses or duo-pitched roof greenhouses) equipped with floor paving guarantee a healthier working environment. These results will be successively compared with measurements carried out in situ in order to evaluate the statistical deviation between the experimental data and those obtained by numeric analysis. Furthermore, the verification in situ of air pollutant concentrations in the open field and inside the greenhouse would reduce the uncertainties linked to the analytical model applied.

However, on the basis of the current study, we can say that the environmental health risk analysis is a valid tool to inspect the health standard of agricultural workplaces and to define possible preventive and protective measures. The flexibility of the applied methodology means it can be expanded to a large number of agricultural areas contaminated with organic pollutants and to different typologies of operative agricultural buildings in order to reduce the morbidity and the death rate connected to the environmental pollution of the workplace. On the other hand, this methodology could be useful to analyse the health risk to farm workers linked to pesticide treatments carried out either in the open field or inside the greenhouse.

Finally, in those polluted areas where the hazard index and the increase in cancer risk exceed legal limits, the environmental health risk must be adequately assessed by direct measurement of pollutant concentrations in order to choose suitable personal protective equipment.

Table 1. Results of site-specific environmental health risk analysis.

\begin{tabular}{|c|c|c|c|c|c|}
\hline $\begin{array}{l}\text { Environmental } \\
\text { pollutant }\end{array}$ & Parameter & $\begin{array}{c}\text { Open field } \\
\text { average value }\end{array}$ & $\begin{array}{l}\text { Greenhouse } \\
\text { average value }\end{array}$ & $\begin{array}{l}\text { Tunnel } \\
\text { average value }\end{array}$ & $\begin{array}{c}\text { Measurement } \\
\text { unit }\end{array}$ \\
\hline Indenopyrene & $\begin{array}{c}V F \\
C_{p o e} \\
H Q \\
R\end{array}$ & $\begin{array}{l}8.98 \mathrm{E}-09 \\
1.54 \mathrm{E}-09 \\
4.31 \mathrm{E}-11 \\
4.19 \mathrm{E}-11\end{array}$ & $\begin{array}{l}1.00 \mathrm{E}-08 \\
1.72 \mathrm{E}-09 \\
4.82 \mathrm{E}-11 \\
4.69 \mathrm{E}-11\end{array}$ & $\begin{array}{l}1.88 \mathrm{E}-08 \\
3.21 \mathrm{E}-09 \\
8.99 \mathrm{E}-11 \\
8.75 \mathrm{E}-11\end{array}$ & $\begin{array}{c}\mathrm{kg} / \mathrm{m}^{3} \\
\mathrm{mg} / \mathrm{m}^{3} \\
\text { Dimensionless } \\
\text { Dimensionless }\end{array}$ \\
\hline Benzo(g,h,i)perylene & $\begin{array}{l}V F \\
C_{p o e} \\
H Q \\
R\end{array}$ & $\begin{array}{l}2.24 \mathrm{E}-08 \\
3.31 \mathrm{E}-09 \\
9.73 \mathrm{E}-09 \\
-\end{array}$ & $\begin{array}{c}7.25 \mathrm{E}-08 \\
1.07 \mathrm{E}-08 \\
3.15 \mathrm{E}-08 \\
-\end{array}$ & $\begin{array}{l}1.31 \mathrm{E}-07 \\
1.95 \mathrm{E}-08 \\
5.71 \mathrm{E}-08 \\
-\end{array}$ & $\begin{array}{c}\mathrm{kg} / \mathrm{m}^{3} \\
\mathrm{mg} / \mathrm{m}^{3} \\
\text { Dimensionless } \\
\text { Dimensionless }\end{array}$ \\
\hline Global hazard index $(H Q)$ & $9.77 \mathrm{E}-09$ & $3.15 \mathrm{E}-08$ & 5.72E-08 & Dimensionless & - \\
\hline Global cancer risk increase $(R)$ & 4.19E-11 & $4.69 \mathrm{E}-11$ & $8.75 \mathrm{E}-11$ & Dimensionless & - \\
\hline
\end{tabular}

Table 2. Comparison among the environmental health risk values inside greenhouses and tunnels with and without flooring.

\begin{tabular}{lcccc} 
& $\begin{array}{c}\text { Greenhouse without } \\
\text { flooring }\end{array}$ & $\begin{array}{c}\text { Greenhouse with } \\
\text { flooring }\end{array}$ & $\begin{array}{c}\text { Tunnel without } \\
\text { flooring }\end{array}$ & $\begin{array}{c}\text { Tunnel with } \\
\text { flooring }\end{array}$ \\
Global hazard index $(H Q)$ & $3.15 \mathrm{E}-08$ & $4.19 \mathrm{E}-11$ & $5.72 \mathrm{E}-08$ & $6.15 \mathrm{E}-10$ \\
Global cancer risk increase (R) & $4.69 \mathrm{E}-11$ & $4.71 \mathrm{E}-13$ & $8.75 \mathrm{E}-11$ & $8.84 \mathrm{E}-13$ \\
\hline
\end{tabular}




\section{References}

ARPA Campania (Regional Agency for Environmental Prevention and Protection). 2009. Monitoraggio ambientale zona acerrana. Available from: http://www.arpacampania.it/index.asp

ASTM (American Society for Testing and Materials). 2000. Standard Guide for Risk-based Corrective Action. Standard E2081 2000.

Barra M.I., Ricciardi P., Terracina A. 2008. Chemical and carcinogenicmagents: health risks and occupational diseases. pp 57-66 in Proc. Congr. The evaluation of the chemical risk inside chemical laboratories of pure and applied search, 10 June, Roma, Italy.

Cecchini M., Monarca D., Guerrieri M., Lingero E., Bessone W., Colopardi F., Menghini G. 2010. Dust exposure for workers during hazelnut harvesting. pp 226-235 in Proc. SHWA, 16-18 September, Ragusa, Italy.

Cerruto E., Balsari P., Oggero G., Friso D., Guarella P., Raffaelli M. 2008. Operator safety during pesticide application in greenhouse: a survey on Italian situation. Acta Horticult. 801:1507-14.

Cicero M.R., Scaini F. 2010. Risk evaluation connected to a diffused contamination of an Italian coast-line. J. Environ. Engine. 9:433-8.

Cividino S.R.S., Troccoli R., Collantoni A., Cecchini M., Monarca D. 2010. Activation of a system for the risks evaluation and the safety management inside the "N. Lupori" didactic-experimental farm. pp 8-17 in Proc. IX AIIA Natl. Congr., 20-22 September, Ischia, Italy.

Cottica D., Grignani E. 2010. Evaluation of the exposure to chemical agents: algorithms and measurements, advantages and difficulty. Ital. J. Med. Jobs Ergonomics 32:113-6.

Gino G. 2010. Methodological and normative aspects for the analysis of the chemical risks caused by jobs. Ital. J. Med. Jobs Ergonomics 32:108-12.

ISPRA (Istituto Superiore per la Ricerca Ambientale). 2008. Criteri metodologici per l'applicazione dell'analisi assoluta di rischio ai siti contaminati. Available from: http:/www.isprambiente.gov.it/ it/archivio/eventi/anno-2005/manualirischiositicontaminati

ISS-ISPESL (Istituto Superiore di Sanità - Istituto Superiore per la Prevenzione E la Sicurezza del Lavoro). 2009a. Banca dati ISSISPESL - Proprietà chimico-fisiche dei contaminanti. Available from: http://www.iss.it/binary/suol/cont/propriet_chim_fis_Banca dati_ISS_ISPESL_Maggio_2009.pdf

ISS-ISPESL (Istituto Superiore di Sanità - Istituto Superiore per la Prevenzione E la Sicurezza del Lavoro). 2009b. Banca dati ISSISPESL - Proprietà tossicologiche dei contaminanti. Available from: http://www.iss.it/binary/suol/cont/prop_toss_Banca_dati_ISS_ISPE SL_Maggio_2009.pdf

Italian Regulation. 2006. Norme in materia ambientale, LD 152/2006. In: Gazzetta Ufficiale no. 88/2006, 3/03/2006.
Italian Regulation. 2006. Norme di attuazione del Protocollo del 23 luglio 2007 su previdenza, lavoro e competitività per favorire l'equità e la crescita sostenibili, nonché ulteriori norme in materia di lavoro e previdenza sociale. LD 247/2007. In: Gazzetta Ufficiale no. 301/2007, 27/12/2007.

Italian Regulation. 2008. Attuazione dell'articolo 1 della legge 3 agosto 2007 , n. 123 , in materia di tutela della salute e della sicurezza nei luoghi di lavoro, LD 81/2008. In: Gazzetta Ufficiale no. 101, 30/04/2008, suppl. ordinario n. 108.

Johnson P, Ettinger R. 1991. Heuristic model for predicting the intrusion rate of contaminant vapours into building. Environ. Sci. Technol. 25:1445-52.

Mausacchio C., Sanvito I. 2012. Flux Chamber: study and definition of the preparation for the evaluation of the soil emissions. J. Solid. Waste 26:108-14.

Nano G. 2010. Models for the evaluation of the exposures. Ital J Med Jobs Ergonomics 32:121-4.

Romano C., Baeli C., Baratti A., Calò B., D’Errico A., Fontana M., Grosso P., Palmas A., Pastore R., Perucca R., Riggio R., Sudano C., Ferraris F. 2011. The algorithms for the chemical risk evaluation: the Piedmont Region experience. Ital. J. Med. Jobs Ergonomics 33:2827.

Russo G., Anifantis C. 2003. Safety at work for greenhouse agricultural productions: structural, equipment and environmental aspects. Proc. C.I.G.R.-CIOSTA Int. Congr., 22-24 September, Torino, Italy, 3:1074-1086.

Scarascia Mugnozza G. 1999. The protected crops: agronomic, territorial and technical-constructive aspects. pp 35-54 in Proc. AIIA seminar, 24-26 June, Ragusa, Italy.

Scarascia Mugnozza G., Sica C., Russo G. 2011. Plastic materials in European agriculture: actual use and perspectives. J. Agricult. Engine. 3:15-28.

Settimi L., Davanzo F., Marcello I. 2007. National system of overseeing for the acute poisonings caused by pesticide: observations carried out in 2005. Reports ISTISAN 2007. Available from: http://www.iss.it/binary/publ/cont/07-51.1203428194.pdf

Tortora A., Sica C., Capobianco R.L. 2005. Workers' health and safety inside greenhouses. pp 1-12 in Proc. VIII AIIA Natl. Congr., 27-30, June, Catania, Italy.

UNICHIM (Associazione per L'unificazione nel Settore dell'Industria Chimica). 2002. Suoli e falde contaminati - Analisi di rischio sito specifica - Criteri e analisi. Manuale no. 196 Parte I. Available from: http://www.unichim.it/index.php?n=Main.HomePage

US EPA. 1997. Exposure factors handbook. Volume I - General factors, EPA/600/P-95/002Fa. United States Environmental Protection Agency, Cincinnati, OH, USA. 